\title{
THE CUSTOMERS' EXPECTATIONS AS A GUIDE TO SERVICE INNOVATION IN THE AIRLINE INDUSTRY
}

Luciana Padovez ${ }^{1}$, Max Well Elias², Mauro Caetano 3

\begin{abstract}
According to the strategic innovation paradigm, service companies have their innovative efforts guided by market needs, so customer demand is crucial to successful innovation. However, the service literature about air transportation has been focusing on the evaluation of service quality delivered instead of the identification of market demands. This study applied the Hierarchical Model of air transportation service quality evaluation adapted to identify customer' expectations in a Brazilian domestic airport. The results indicate that customers have higher expectations regarding airline employees' conduct and expertise, which suggests areas where investments should be prioritized in order to optimize efforts on service innovation.
\end{abstract}

\section{KEYWORDS}

customers' expectation; innovation; service quality; air transport; airlines; services.

\footnotetext{
${ }^{1}$ Federal University of Goiás (UFG), Administration Postgraduate Program (PPGADM/FACE), Research Group on Air Transport Innovation Management.

PhD student in Administration (University of Brasilia - UNB), Brazil.

Email: lu_padovez@yahoo.com.br

${ }^{2}$ Federal University of Goiás (UFG), Research Group on Air Transport Innovation Management.

B.Sc., Business Administration (Federal University of Goiás - UFG), Brazil.

Email: maxwellelias@outlook.com

${ }^{3}$ Federal University of Goiás (UFG), Administration Postgraduate Program (PPGADM/FACE), Research Group on Air Transport Innovation Management.

Postdoc in Aeronautics Infrastructure Engineering (Aeronautics Institute of Technology - ITA) and Production Engineering, Ph.D (University of São Paulo - USP), Brazil.

Email: maurocaetano1912@gmail.com
} 


\section{INTRODUCTION}

Providing high quality services is crucial for airline companies to increase profitability and market share (Wu \& Cheng, 2013). In spite of that, some reports such as the Air Travel Consumer Report e JD Power Airline Satisfaction Study show that customers are not completely satisfied with the service provided by airlines (Waguespack \& Rhoades, 2014). According to the authors, the disquality rates are calculated with data from the percentage of late flights, total number of customer complaints, total number of involuntary denied boardings, total number of mishandled baggage reports and cancellations.

Attempting to offer better services to customers and increase profitability, airlines innovate in services. Some examples of air transport service innovation developed in the past years that are becoming mass services are: on line check-in, self-check-in kiosks, web-booking with up sell offer, one-way ticket pricing, limousine service, empty middle seat, mobile phone usage onboard, live TV/radio, onboard bar and lie-flat seat (Rothkopf \& Wald, 2011). Those innovations are incremental and create ancillary revenues (O'Connel \& Warnock-Smith, 2013). However, the fees for these services, which apparently increase profits, are one of the main complaints of airline customers (Waguespack\& Rhoades, 2014).

Therefore, airlines must understand their customers' expectations to improve service superiority and market performance, creating value (Carbonell, 2009). In that sense, customer interaction can provide a more accurate understanding of customer's wants and needs and prevent against the development of bad and undesired services that will not be accepted in the market (Alam \& Perry, 2002).

The strategic innovation paradigm states that innovations are market-driven, meaning that the market situation is an important factor for determining the innovation's success (Sundbo, 1997). Market orientation requires learning about customers' needs, competition, environmental forces and customer involvement aims to facilitate the process of sensing the market (Matthing, Sanden \& Edvardsson, 2004). Additionally, the literature on airline services has prioritized service quality issues in spite of customers' expectations.

This paper aims to identify customers' expectations, answering what clients want from air transport innovation and indicating innovation priorities for the companies. For that matter, the Hierarchical Model of air transportation was adapted and applied, because it is a multidimensional instrument with four primary dimensions and eleven sub-dimensions, which help elaborate management strategies and tactics and improving performance (Wu \& Cheng, 
2013). The adaptation process included using the techniques from Analytic Hierarchy Process (AHP) to provide decisions that are more objective from customers (Saaty, 2008) and understand the true level of importance of each dimensions.

\section{AIRLINE SERVICE QUALITY}

Quality is a manifold concept and is related to satisfying the needs of the stakeholders of the organization, including customers, owners and staff (Edvardsson \& Olsson, 1996). It is usually defined as a form of evaluation of a product or service, a condition of global judgment, while satisfaction is related to a specific transaction. As satisfaction episodes accumulate over time, the customer develops a perception of service quality (Parasuraman, Zeithaml \& Berry, 1988).

Service quality is the most important matter in obtaining service sector competitive advantage and financial success (Parasuraman, Zeithaml \& Berry, 1988). Customers are the final evaluators of service quality and if they are unhappy, they will share their dissatisfaction with people they know (Cheung \& To, 2011). Therefore, many studies have tried to investigate the service quality attributes in the airline industry.

The quality dimensions studied are usually tangibles, responsiveness, reliability, empathy, safety (Pakdil \& Aydin, 2007; Chou et al, 2011; Mitra, 2014), cabin service (Liou et al., 2011; Wong\& Chung, 2007), flight patterns, image, availability (Pakdil \& Aydin, 2007), and communications (Hussain et al., 2014). Table 1 summarizes service quality research and its main results. 
Table 1: Service Quality Research

\begin{tabular}{|c|c|c|c|}
\hline Source & Method & Respondents & Main results \\
\hline $\begin{array}{l}\text { Basfirinci and } \\
\text { Mitra (2014) }\end{array}$ & $\begin{array}{l}\text { SERVQUAL and } \\
\text { Kano Model }\end{array}$ & $\begin{array}{l}238 \text { respondents (126 from Turkey } \\
\text { and } 112 \text { from USA). }\end{array}$ & $\begin{array}{c}\text { For US airlines and Turkish airlines, quality delivered is bellow customers' } \\
\text { expectations; cultural differences influence customers' expectations and } \\
\text { perceptions of service quality affecting satisfaction. }\end{array}$ \\
\hline $\begin{array}{l}\text { Chou et al. } \\
\text { (2011) }\end{array}$ & $\begin{array}{l}\text { Fuzzy weighed } \\
\text { SERVQUAL }\end{array}$ & $\begin{array}{l}329 \text { passengers from an international } \\
\text { airline that flies from International } \\
\text { Airport of Kaohsiung in Taiwan. }\end{array}$ & $\begin{array}{l}\text { Passengers consider reliability and assurance dimension and safety-related } \\
\text { services items as top priorities. }\end{array}$ \\
\hline $\begin{array}{l}\text { Hussain et al. } \\
\text { (2014) }\end{array}$ & SERVQUAL & $\begin{array}{l}253 \text { respondents from Dubai } \\
\text { International Airport. }\end{array}$ & $\begin{array}{l}\text { Superior service quality, perceived value and corporate image create passenger } \\
\text { satisfaction and lead to brand loyalty. }\end{array}$ \\
\hline $\begin{array}{l}\text { Laming and } \\
\text { Mason } \\
(2014)\end{array}$ & $\begin{array}{l}\text { Survey (Airs@t } \\
\text { survey) }\end{array}$ & $\begin{array}{l}18.567 \text { passengers from } 15 \text { airlines } \\
\text { (five based in Asia, seven in Europe } \\
\text { and three in the Middle East). }\end{array}$ & $\begin{array}{l}\text { Satisfaction is derived specially from cabin features, crew and pilot performance, } \\
\text { and in-flight food and drink and these items crate customer loyalty. }\end{array}$ \\
\hline $\begin{array}{l}\text { Liou et al. } \\
\text { (2011) }\end{array}$ & Modified VIKOR & $\begin{array}{l}5598 \text { passengers from UNI Air, } \\
\text { TransAsia Airways, Mandarin Airlines } \\
\text { and Daily Air. }\end{array}$ & $\begin{array}{l}\text { Cabin services are considered the most important dimension of service quality; } \\
\text { the services with higher satisfaction levels are reservation, ticketing, check-in } \\
\text { and boarding processes. The lower satisfaction levels refer to baggage claim and } \\
\text { handling delays. }\end{array}$ \\
\hline $\begin{array}{l}\text { Pakdil and } \\
\text { Aydin (2007) }\end{array}$ & $\begin{array}{l}\text { Weighed } \\
\text { SERVQUAL }\end{array}$ & $\begin{array}{l}320 \text { passengers from an airline in } \\
\text { Istanbul Ataturk International Airport. }\end{array}$ & $\begin{array}{l}\text { Passengers' past experience is the most important reason in choosing an airline; } \\
\text { passengers' education levels affect their expectations and perceptions; the } \\
\text { "responsiveness" dimension is the most important and "availability" is the least. }\end{array}$ \\
\hline $\begin{array}{l}\text { Wong and } \\
\text { Chung } \\
(2007)\end{array}$ & $\begin{array}{l}\text { SERVQUAL and } \\
\text { C5.0 decision } \\
\text { tree }\end{array}$ & $\begin{array}{c}812 \text { passengers from a Taiwanese } \\
\text { Airline. }\end{array}$ & Passengers like responsive, reliable and assured air transport service. \\
\hline
\end{tabular}


The Hierarchical Model proposes that service quality consists of four primary dimensions composed by sub-dimensions. The first dimension is interaction quality. It refers to the personal interface between service providers and customers during service delivery and its sub-dimensions are conduct, expertise and problem solving. The second dimension is physical environment quality, referring to the physical characteristics of the service production process and its sub-dimensions are cleanliness, comfort and tangibles. The third dimension, outcome quality, focuses on what customers obtain from the service and its subdimensions are valence and waiting time. The fourth dimension, access quality, refers to the ease and speed with which people reach the desired location and its sub-dimensions are information and convenience (Wu \& Cheng, 2013).

The dimensions should be considered when developing management strategies, while the sub-dimensions can be analyzed when formulating daily management tactics. The combinations of those areas compose the general perception of airline service quality (Wu \& Cheng, 2013).

\section{SERVICE INNOVATION AND CUSTOMER' EXPECTATIONS}

Many quality problems are caused by drawbacks in the development of new services. When developing a new service, the right quality must be built from the beginning, planning the development of services which customers see as appealing (Edvardsson \& Olsson, 1996). The new service development process comprises four stages: idea generation, idea transformation, development and implementation. When developing a new service it is crucial to learn from and with customers, because they are a "potential goldmine" and help create value (Edvardsson et al., 2012). To deeply understand clients' needs and wants it is necessary to involve them in the new service developing process (Gustafsson, Ekdahl \& Edvardsson, 1999).

Customers might get involved with the service depending on how important and meaningful that service is for them. The more involved a customer is with a service, the more customers' expectations will influence the evaluation of service performance. Therefore, companies should stimulate and try to increase customer involvement in order to obtain better ideas for new service development and achieve higher satisfaction levels (Cheung \& To, 2011). 
When developing new air transport services, involving customers helps tailoring the service and create unique experiences that enhance loyalty. The higher the degree of co-creation, the higher the financial (profits) and non-financial (loyalty and satisfaction) levels of the company. The value is created not only in the delivery of the service itself, but also in the development process, because the customer feels special and useful for the company (Grissemann \& Stokburger-Sauer, 2012).

The idea generation phase is the most important stage in the development of new services, because it helps develop services that match customer's needs, especially if clients are involved in the process. In this phase, clients can contribute as they state needs, problems and solutions, criticize existing services, help identify gaps in the market and can provide a wish list of the services wanted (Alam \& Perry, 2002). In the idea generation phase, companies should identify customers' expectations and design services that serve them (Edvardsson \& Olsson, 1996).

As quality is a comparison of how the customers feel the service and how should be the perception of the service offered, as more companies know about customers' expectations, more quality it can provide by trying to achieve that expectation (Parasuraman, Zeithaml \& Berry, 1988).

The customer' expectations are what clients want or wish for, what they think the company should provide them and not only what the company would provide (Parasuraman, Zeithaml \& Berry, 1988; Zeithml, 1993; Edvardsson \& Olsson, 1996). They are previous beliefs that are used as standards or references to judge the service that is provided, determining customers' satisfaction and service performance. Two clients can have different expectations about the same service. That is why organizations in the same business can have completely different service levels and still maintain customers satisfied (Zeithml, 1993).

Expectation construct is fundamental in determining the quality evaluations. Perceived service quality is the difference between customers' perceptions and desires. The desired service is the one the client hopes to get, that will attend all of his needs and surprise him. It mixes what services can be and should be. As customers know that it is not always possible, they can have a lower level of expectation that is still acceptable, called the adequate service level which customers will accept (Parasuraman; Zeithaml; Berry, 1988). 
Expectations can be influenced by the company's image and reputation, the clients' previous experience with the company, marketing campaigns (Edvardsson; Olsson, 1996), personal needs, situational factors, past experience, word of mouth communication, advertising, personal selling, perceived alternative services and service promises (Parasuraman; Zeithaml; Berry, 1988).

\section{METHODOLOGY}

The research was conducted in a Brazilian domestic airport located in São Paulo (CGH) in January, 2015. This airport was chosen because it is one of the most important and busy airports in the country, with more than 200 thousand landings and takeoffs per year and around 20 million passengers in 2015, being behind in Brazil only of the Guarulhos Airport (GRU), with approximately 300 thousand annual landings and takeoffs and more than 38 million passengers in the same year (DECEA, 2016; INFRAERO, 2016). The convenience sampling technique was used for data collection. One hundred and twenty-two passengers that were waiting to board their flights answered the questionnaire in the airport lounge. Twenty-two of these questionnaires were incomplete and thus excluded from data analysis, resulting one hundred valid questionnaires. It is believed that this amount of interviewees, even if small, can be used as an initial reference for the study of the subject in this paper.

The Hierarchical Model for air transportation was adapted in order to measure expectations instead of service quality. The dimensions conduct, expertise, problem-solving, cleanliness, comfort, tangibles, safety \& security, valence, waiting time, information and convenience of the Hierarchical Model were compared against each other in pairs, using the Analytic Hierarchy Process method (AHP) to provide more objective assessments from customers (Saaty, 2008) and understand each true level of importance of dimensions regarding customers' expectations. An example of this method is shown in Table 2.

Table 2: Some of the questions applied using the AHP method

\begin{tabular}{|c|c|c|c|c|}
\hline $\begin{array}{c}\text { In your opinion, this } \\
\text { item below is... }\end{array}$ & $\begin{array}{c}\text { More } \\
\text { important }\end{array}$ & $\begin{array}{c}\text { Equally } \\
\text { important }\end{array}$ & $\begin{array}{c}\text { Less } \\
\text { important }\end{array}$ & ...than this item? \\
\hline \multirow{3}{*}{$\begin{array}{c}\text { Employees' conduct } \\
\ldots\end{array}$} & $\square$ & $\square$ & $\square$ & Employees' expertise \\
\cline { 2 - 5 } & $\square$ & $\square$ & $\square$ & $\begin{array}{c}\text { Employees' ability to } \\
\text { solve problems }\end{array}$ \\
\cline { 2 - 5 } & $\square$ & $\square$ & $\square$ & Aircraft' cleanliness... \\
\hline
\end{tabular}


The AHP method used with passengers by the Table 2 was applied by means of a questionnaire. The questionnaire was constructed with questions designed to assess customers' expectations through AHP, through the comparative analysis of the level of importance between the variables by the passengers, and questions that aimed to define passengers' demographic characteristics.

The questions that sought to assess customers' expectations compared two dimensions at a time in order to determine whether the respondent held higher expectations for a certain dimension or if he/she had equal expectations for both. If certain dimension was considered more important than the other one it was being compared to, the more important dimension should score 3 points and the less important dimension should score 1 point in the data analysis. If the importance weights were the same, both should score 2 points. Since eleven dimensions were analyzed in pairs, it was needed fifty-five comparisons in order to evaluate all of the possible relationships between pairs of variables.

\section{RESULTS}

The passengers' demographic characteristics answered are summarized in Table 3. As shown in Table 3, out of the one hundred respondents, $67 \%$ were males and $33 \%$ were females. Regarding respondents' ages, $61 \%$ are from 21 to 40 years old, and $88 \%$ of respondents have at least higher education and the majority of passengers - $63 \%$ of them were on a business trip. $40 \%$ of respondents use air transportation from 3 to 6 times a year, while the second biggest group uses it 11 times or more per year (30\%).

Table 3: Sample Characteristics

\begin{tabular}{cccc}
\hline Measure & Option & Frequency & $\mathbf{\%}$ \\
\hline Gender & Male & 67 & $67 \%$ \\
& Female & 33 & $33 \%$ \\
\multirow{2}{*}{ Age } & 20 years old or younger & 11 & $11 \%$ \\
& $21-30$ & 34 & $34 \%$ \\
& $31-40$ & 27 & $27 \%$ \\
& $41-50$ & 17 & $17 \%$ \\
& $51-60$ & 8 & $8 \%$ \\
& 60 years old or older & 3 & $3 \%$ \\
\hline
\end{tabular}




\begin{tabular}{cccc}
\hline Measure & Option & Frequency & \% \\
\hline \multirow{2}{*}{ Education } & Elementary school or below & 0 & $0 \%$ \\
& High school & 12 & $12 \%$ \\
& Higher education & 53 & $53 \%$ \\
Trip purpose & Post graduate & 35 & $35 \%$ \\
& Leisure/Tourism & 31 & $31 \%$ \\
& Business & 63 & $63 \%$ \\
Annual frequency of air travel in the & Others & 6 & $6 \%$ \\
last 12 months & & & \\
& 2 or less & 16 & $16 \%$ \\
& $3-6$ & 40 & $40 \%$ \\
& $7-10$ & 14 & $14 \%$ \\
& 11 or more & 30 & $30 \%$ \\
\hline
\end{tabular}

To classify the dimensions analyzed according to customers' expectations, it is used a total score for each variable. The total scores are composed by the sum of all individual scores a dimension received by respondents in the questionnaire. Table 4 presents the AHP matrix as well as the total scores each dimension received, in which the higher the total score a dimension received, the higher customers have high expectations for this dimension. Fig. 1 orderly classifies the dimensions importance in terms of customers' expectations by using the percentage of the sum of all total scores a dimension has.

Thereby, Figure 1 shows that, among all dimensions of service quality inherent to the Hierarchical Model of air transportation service quality, customers have higher expectations regarding airline's conduct and expertise. 
Table 4: AHP matrix

\begin{tabular}{|c|c|c|c|c|c|c|c|c|c|c|c|c|}
\hline Dimensions & Conduct & Expertise & $\begin{array}{c}\text { Problem- } \\
\text { solving }\end{array}$ & Cleanliness & Comfort & Tangibles & $\begin{array}{l}\text { Safety \& } \\
\text { security }\end{array}$ & Valence & $\begin{array}{l}\text { Waiting } \\
\text { time }\end{array}$ & Information & Convenience & $\begin{array}{l}\text { Total } \\
\text { scores }\end{array}$ \\
\hline Conduct & - & 223 & 229 & 237 & 218 & 227 & 220 & 220 & 211 & 218 & 213 & 2216 \\
\hline Expertise & 177 & - & 236 & 225 & 222 & 223 & 227 & 220 & 223 & 213 & 220 & 2186 \\
\hline Problem-solving & 171 & 164 & - & 239 & 232 & 210 & 225 & 222 & 223 & 228 & 218 & 2132 \\
\hline Cleanliness & 163 & 175 & 161 & - & 204 & 203 & 184 & 203 & 186 & 193 & 199 & 1871 \\
\hline Comfort & 182 & 178 & 168 & 196 & - & 203 & 190 & 223 & 209 & 209 & 212 & 1970 \\
\hline Tangibles & 173 & 177 & 190 & 197 & 197 & - & 212 & 219 & 208 & 216 & 207 & 1996 \\
\hline Safety \& security & 180 & 173 & 175 & 216 & 210 & 188 & - & 262 & 250 & 255 & 248 & 2157 \\
\hline Valence & 180 & 180 & 178 & 197 & 177 & 181 & 138 & - & 217 & 214 & 217 & 1879 \\
\hline Waiting time & 189 & 177 & 177 & 214 & 191 & 192 & 150 & 183 & - & 221 & 219 & 1913 \\
\hline Information & 182 & 187 & 172 & 207 & 191 & 184 & 145 & 186 & 179 & - & 226 & 1859 \\
\hline Convenience & 187 & 180 & 182 & 201 & 188 & 193 & 152 & 183 & 181 & 174 & - & 1821 \\
\hline
\end{tabular}

Figure 1: Customers' expectations classification

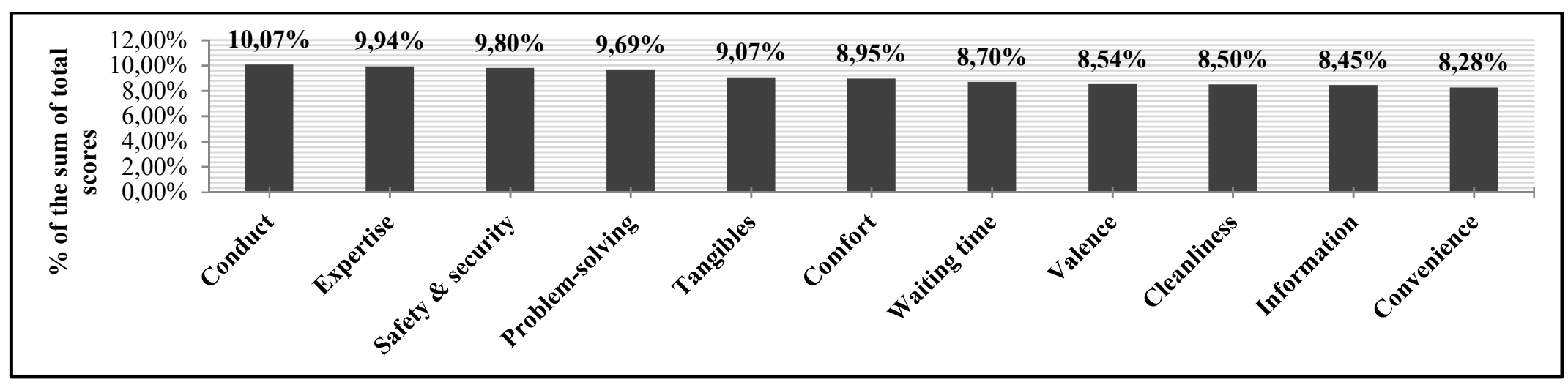


The conduct dimension in the Hierarchical Model of air transportation service quality comprises the airline employees' willingness to help customers, the airline employees' friendly behavior and their understanding of customer needs, the sense of trust passed on by their behavior and the quality of service provided by them, the sense that customers can rely on airline employees to take actions in order to satisfy customers' needs.

Regarding the items that form the conduct dimension, all of them are related to airline employees' behavior, thus indicating an area of extreme importance for airlines to have good performance and also to seek ways of generating innovation in order to increase the level of service offered, since this is the dimension customers have higher expectations about.

The second dimension to which customers have more expectations about is the expertise dimension, which is formed by three items: the conscience of employees that customers depend on their professional knowledge to have their needs satisfied, the confidence that customers can count on the airline employees knowing their jobs and responsibilities and, finally, the airline employees' competence. Similarly to the conduct dimension, the expertise dimension also is completely related to the airlines' employees, reinforcing the critical importance of the airlines' employees to the quality of service received by customers in the airline industry.

\section{CONCLUSIONS}

The purpose of creating new services is to enhance profitability as the company retain clients and obtain new ones as they became loyal and satisfied (Gustafsson; Ekdahl; Edvardsson, 1999). This paper aimed to answer the question: what do clients want? Considering the customers' high expectations related to conduct and expertise, companies should innovate primarily in those two dimensions in order to meet customers' expectations, thus delivering a higher quality of service, and optimize efforts on service innovation.

This findings of this research should assist airlines' managers as it highlights the importance of human resources in the airline industry, thus indicating that managerial actions regarding human resources management, such as having good recruiting and selection processes, as well as offering adequate training in order to raise employees' expertise concerning their functions, could help airline companies to elevate their quality of service delivered and consequently strengthen their position against competitors. 
As limitations of the study, we point the convenience sample, as the research was conducted in a Brazilian airport and the sample size was relatively small (one hundred valid answers). Even so, the research has important implications for both theory and practice as little effort has been made to understand what customers want regarding airline services. Future research should continue on this path, in order to help increase customers' satisfaction and airlines' profitability.

\section{REFERENCES}

Alam, I., \& Perry, C. (2002). A customer oriented new service development process. Journal of Services Marketing, 16(6), 505-534.

Basfirinci, C., \& Mitra, A. (2015). A cross cultural investigation of airlines service quality through integration of Servqual and the Kano model. Journal of Air Transport Management, 42, 239-248.

Carbonell, P., Rodriguez-Escudero, A. I., \& Pujari, D. (2009). Customer involvement in new service development: an examination of antecedents and outcomes. Journal of Product Innovation Management, 26, 536-550.

Cheung, M. F. Y., \& To, W.M. (2011). Customer involvement and perceptions: the moderating role of customer co-production. Journal of Retailing and Consumer Services, 18, 271-277.

Chou, C., Liu, L. Huang, S., Yih, J., \& Han, T. (2011). An evaluation of airline service quality using the fuzzy weighted SERVQUAL method. Applied soft computing, 11, 2217-2128.

DECEA, Departamento de Controle do Espaço Aéreo (2016). Aeroportos mais movimentados do país, Brasil.

Edvardsson, B., \& Olsson, J. (1996). Key concepts for new service development. The Service Industries Journal, 16(2), 140-164.

Edvarsson, B., Kristensson, P., Magnusson, P. \& Sundstrom, E. (2012). Customer integration within service development - a review of methods and an analysis of insitu and exsitu contributions. Technovation, 32, 419-429.

Grissemann, U. S., \& Stokburger-Sauer, N. E. (2012). Customer co-creation of travel services: the role of company support customer satisfaction with the co-creation performace. Tourism Management, 33, 1483-1492.

Gustafsson, A., Ekdahl, F., \& Edvardsson, B. (1999). Customer focused service development in practice: a case study in Scandinavian Airlines System. International Journal of Service Industry Management, 10, 344-358. 
Hussain, R., AL Nasser, A., \& Hussain, Y. (2015). Service quality and customer satisfaction of a UAE-based airline: An empirical investigation. Journal of Air Transport Management, 42, 167-175.

INFRAERO (2016). Anuário estatístico operacional 2015. Brasília, Apr.

Laming, C., \& Mason, K. (2014). Customer experience - an analysis of the concept and its performance in airline brands. Research in Transportation Business \& Management, $10,15-25$.

Liou, J. J. H., Tsai, C., Lin, R. \& Tzeng, G. (2011). A modified VIKOR multiple-criteria decision method for improving domestic airlines service quality. Journal of Air Transport Management, 17, 57-61.

Matthing, J., Sanden, B., \& Edvarsson, B. (2004). New Service Development: learning from and with customers. International Journal of Services, 15(5), 479-498.

O'Connell, J. F., \& Warnock-Smith, D. (2013). An investigation into traveler preferences and acceptance levels of airline ancillary revenues. Journal of Air Transport Management, $33,12-21$.

Pakdil, F., \& Aydin, O. (2007). Expectations and perceptions in airline services: An analysis using weighted SERVQUAL scores. Journal of Air Transport Management, 13, 229-237.

Parasuraman, A., Zeithaml, V.A., \& Berry, L. L. (1988). Servqual: A multiple-item scale for measuring consumer perceptions of service quality. Journal of Retailing, 64(1), 12-40.

Rothkopf, M., \& Wald, A. (2011). Innovation in commoditized services: a study in the passenger airline industry. International Journal of Innovation Management, 15(4), 731-753.

Saaty, T. (2008). Decision making with the analytic hierarchy process. International Journal of Services Sciences, 1(1), 83-98.

Stuart, F. I., \& Tax, S. S. (1996). Planning for service quality: an integrative approach. International Journal of Service Industry Management, 74 ), 58-77.

Sundbo, J. (1997). Management of innovation in services. Service Industries Journal, 1Л3), 432-455.

Thakur, R., \& Hale, D. (2013). Service innovation: a comparative study of U.S. and Indian service firms. Journal of Business Research, 66, 1108-1123.

Waguespack, B.P., \& Rhoades, D. L. (2014). Twenty five years of measuring airline service quality or why is airline service quality only good when times are bad? Research in Transportation Business \& Management, 10, 33-39. 
Wong, J., \& Chung, P. (2007). Managing valuable Taiwanese airline passengers using knowledge discovery in database techniques. Journal of Air Transport Management, $13,362-370$.

Wu, H., \& Cheng, C. (2013). A hierarchical model of service quality in the airline industry. Journal of Hospitality and Tourism Management, 20, 13-22. 